\title{
$\mathrm{JEA}$

\section{Pengaruh Skema Kompensasi dan Religiusitas terhadap Penilaian Etis Manager atas Investasi Berlebihan pada CSR}

\author{
Herman Muliawan $^{1 *}$, Sany Dwita ${ }^{2}$, Nayang Helmayunita ${ }^{3}$ \\ $1^{*, 2,3}$ Jurusan Akuntansi, Fakultas Ekonomi, Universitas Negeri Padang \\ *Korespondensi: hermanmuliawan48@gmail.com
}

\begin{abstract}
This study aims to examine the effect of pay scheme and religiousity on managers' ethical judgements in regards to overinvestment in corporate social responsibility. The population in this study were students of the Master Program in the Faculty of Economics, Padang State University. A total of 57 people agreed in this study.Laboratory experiments with a $2 \times 2$ factorial design were carried out. 57 MM students participate in an experiment. Data analysis was done by using two-way ANOVA. is used at Hypothesis test. The results of this study conclude that pay scheme affects an managers' ethical judgements in regards to overinvestment in corporate social responsibility with a significance value of the two-way ANOVA analysis test of $0.003<0.05$. Religiousity affects an managers' ethical judgements in regards to overinvestment in corporate social responsibility. The significance value of the twoway ANOVA analysis test was $0.000<0.05$
\end{abstract}

Keywords: Corporate social responsibility; Overinvestment; Payscheme; Religiousity

How to cite

Muliawan, Herman., Dwita, Sany., Helmayunita, Nayang. (2021). Pengaruh Skema Kompensasi dan Religiusitas terhadap Penilaian Etis Manager atas Investasi Berlebihan pada CSR. Jurnal Eksplorasi Akuntansi, 3(2), 264-278.

\section{PENDAHULUAN}

Perwujudan konsep bisnis yang berorientasi pada daya saing dan reputasi bisnis jangka panjang dengan memberikan perhatian lebih pada tanggung jawab sosial perusahaan atau Corporate Social Responsibility (CSR). Corporate Social Responsibility (CSR) menurut Mc Williams dan Siegel (2000) adalah gambaran dari tindakan perusahaan tak terbatas pada pemenuhan tujuan ekonomi perusahaan dan tujuan-tujuan lain berdasarkan ketetapan hukum, tetapi mencakup tindakan-tindakan untuk kepentingan sosial. CSR juga dapat diartikan sebagai investasi karena biaya yang dikeluarkan akan memberikan manfaat pada masa yang akan datang untuk meningkatkan nilai perusahaan tersebut (Yosefin, 2012) dalam Wahyuni et al., (2019).

Corporate Social Responsibility menjadi isu menarik dalam praktik bisnis untuk masa dekade terakhir saat ini (Ferreira dan Oliveira, 2014). Perusahaan yang melibatkan diri dalam aktivitas CSR biasanya dipandang sebagai perusahaan yang melakukakan kebaikan (Wood, 2010), sehingga aktivitas CSR sering dipandang sebagai fenomena positif yang berdampak positif pula pada kinerja organisasional. Hal ini ditandai pada penelitian yang dilakukan para ahli sebelumnya didominasi oleh penelitian yang menguji dampak positif dari CSR, dapat 
dilihat pada hasil penelitian Porter dan Kramer (2006) dalam Kusuma dan Sholihin (2016). Penelitian-penelitian sebelumnya tidak mempertimbangkan adanya kemungkinan praktik perilaku-perilaku tidak etis dan oportunistik manajemen melalui aktivitas CSR.

Beberapa tujuan manager bertindak tida etis dan oportunistik secara empiris, diantaranya dari hasil penelitian yaitu untuk alasan politis (Kao et al., 2014), alasan untuk kepentingan diri senidir (Lei et al., 2014), mengurangi dampak dari tindakan-tindakan tidak baik perusahaan sebelumnya (Hemingway dan McLagan, 2004), menutupi tindakan perusahaan terkait dengan manajemen laba (Petrovits, 2006 dan Prior et al., 2008). Kinasih et al., (2018) dalam penelitiannya menyatakan bahwa aktivitas CSR dapat dijadikan alat untuk menutupi tindakan tida etis yang dilakukan perusahaan. Investigasi terhadap fenomena penilaian etis manajer atas investasi berlebih pada CSR diperlukan oleh organisasi karena perilaku tidak etis secara moral tidak bisa diterima karena berbahaya bagi orang lain dan lingkungan (Thoyibatun, 2012). Hal ini membuat ketertarikan peneliti untuk meneliti faktor yang mempengaruhi penilaian etis manajer atas investasi berlebih pada CSR.

Faktor pertama yang diduga mempengaruhi penilaian etis manajer atas investasi berlebih pada CSR yaitu skema kompensasi. Penelitian yang mencoba menghubungkan skema kompensasi dengan penilaian etis manajer atas investasi berlebih pada CSR dalam penelitian masih sedikit ditemukan dan mendapatkan hasil penelitian yang belum konsisten.Hal ini memotivasi peneliti untuk melakukan penelitian dengan menguji pengaruh skema kompensasi sebagai satu dari banyak faktor yang mempengaruhi penilaian etis manajer atas investasi berlebih pada CSR. Menurut Wahyuni et al., (2019) skema kompensasi berpengaruh signifikan terhadap penilaian etis manajer atas investasi berlebih pada CSR. Manajer dengan overinvestment hindering payscheme (skema kompensasi tidak berbasis kinerja) lebih cenderung menilai investasi berlebihan pada CSR sebagai tindakan yang tidak etis dibandingkan manajer dengan overinvestment inducing pay scheme (skema kompensasi berbasis kinerja).

Pada penelitian ini pendekatan teori atribusi dianggap lebih sesuai digunakan untuk meneliti penilaian etis manajer atas investasi berlebih pada CSR karena dalam teori atribusi dijelaskan penyebab seseorang melakukan perilaku tertentu. Argumen ini mendukung teori atribusi menurut Lubis (2014) yaitu teori terkait penyebab atas suatu perilaku individu. Kusuma dan Sholihin (2016) dalam penelitiannya menggunakan skema kompensasi sebagai variabel independen dan menggunakan teori keadilan sebagai pendekatan teori menemukan bahwa skema kompensasi dapat menciptakan bias egosentrik yang berpengaruh pada persepsi manajer atas keadilan, yang selanjutnya mempengaruhi keputusan etis manajer atas investasi berlebih pada CSR. Penelitian Hobson et al., (2011), menyebutkan bahwa skema kompensasi berpengaruh signifikan terhadap penilaian etis suatu individu, namun konteks pada penelitian ini adalah skema kompensasi yang mempengaruhi manager yang terlibat dalam tindakan tidak etis yaitu menciptakan senjangan anggaran, akan menilai tindakan tersebut sebagai tindakan yang tidak etis dibandingkan skema kompensasi yang memberikan insentif terhadap bawahan yang bertindak etis.

Selain skema kompensasi, religiusitas juga diduga mempengaruhi penilaian etis manager atas investasi berlebih pada CSR. Religiulitas merupakan topik yang penting dikembangkan dan masih sedikit ditemukan pada penelitian-penelitian sebelumnya. Religiulitas juga merupakan faktor dominan yang mempengaruhi nilai-nilai sosial yang berdampak pada pengembangan nilai-nilai akuntansi (Pramono, 2012). Pemilihan variabel religiulitas pada penelitian ini adalah agar berbeda dari penelitian sebelumnya yaitu penelitian yang dilakukan oleh Wahyuni et al., (2019) dan untuk mengetahui apakah ada perbedaan penilaian etis manajer yang memiliki tingkat religiulitas tinggi dan tingkat religiulitas rendah terhadap investasi berlebih pada CSR. 
Religiusitas menurut Sulistiani (2011) dalam Pratama et al., (2020) merupakan pemahaman individu secara menyeluruh terhadap ajaran agama yang dianutnya, serta mengaplikasikan ajaran agama yang didapat kedalam kehidupan sehari-hari, baik melalui interaksi sosial maupun hubungan antar sesama. Hasil penelitian Samroh (2019) menunjukkan bahwa seorang yang memiliki religiulitas yang tinggi, maka akan tinggi pula perilaku yang dalam kehidupannya karena mampu menahan perilaku yang tidak baik dalam hal ini mendukung teori tindakan berpikir (theory reasoned action). Menurut Pratama et al., (2020), teori tindakan berpikir menjelaskan seseorang bertindak atas keyakinan dirinya serta sikap dan perilaku yang mendasari tindakannya tersebut. Sikap merupakan evaluasi kepercayaan atas perasaan positif atau negatif seseorang. Religiulitas merupakan hal pribadi individu sehingga akan mempengaruhinya untuk bersikap. Karena agama adalah keyakinan seseorang, sehingga niat seseorang untuk berperilaku positif dipengaruhi oleh faktor pribadi seseorang yang memutuskan melakukan tindakan atau berperilaku untuk melakukan investasi berlebih pada CSR.

Penelitian-penelitian terdahulu juga membuktikan bahwa seseorang yang memiliki tingkat religiusitas yang tinggi akan mempertimbangkan segala perilakunya sesuai ajaran agama yang dianutnya (Hutahahean dan Hasnawati, 2015). Wong (2008) menemukan ada hubungan yang kuat antara tingkat religious seseorang dengan penilaian etis yang dimiliki. Penelitian Woodbine et al., (2009) menemukan semua agama dan sistem kepercayaan hampir keseluruhannya memiliki aturan bagi semua penganutnya agar berperilaku etis pada semua aspek kehidupan termasuk bisnis. Grasmick et al.,(1991) dalam Basri (2015) menyatakan bahwa kuatnya keyakinan agama seseorang diharapkan dapat mencegah perilaku ilegal melalui perasaan bersalah terutama dalam hal perilaku etis. Hal ini juga berlaku pada etika untuk investasi berlebih pada CSR.

Tujuan dari penelitian ini ialah untuk mengetahui pengaruh skema kompensasi dan religiulitas terhadap penilaian etis manager atas investasi berlebih pada CSR. Dari sekian banyak yang mempengaruhi penilaian etis manager atas investasi berlebih pada CSR, skema kompensasi dan religiulitas menjadi piliha peneliti. Peneliti menyimpulkan bahwa skema kompensasi dan religiulitas memiliki peran penting dalam penilaian etis manager, maka hal tersebut membuat peneliti tertarik untuk meneliti dengan judul "Pengaruh Skema Kompensasi dan Religiusitas Terhadap Penilaian Etis Manajer Atas Investasi Berlebihan Pada CSR”.

\section{REVIU LITERATUR DAN HIPOTESIS Teori Atribusi (Atribution Theory)}

Teori atribusi pertama kali dicetuskan oleh Fritz Heider (1958) merupakan teori berhubungan dengan perilaku seseorang, bagaimana seseorang dapat menjelaskan penyebab perilaku diri sendiri atau orang lain yang ditentukan dari internal seperti sifat, karakter, sikap dan lainnya, maupun eksternal seperti tekanan situasi atau keadaan tertentu yang berpengaruh terhadap perilaku individu (Luthans, 2005). Menurut Harold Kelley (1972-1973) dalam Rahmi dan Sovia (2017), dalam teori atribusi dijelaskan bagaimana inidividu menarik kesimpulan terkait "apa yang menjadi sebab", apa dasar individu melakukan suatu perbuatan atau memutuskan untuk berbuat dengan cara tertentu.

Dasar pertimbangan orang untuk menarik kesimpulan apakah sebuah tindakan atau perbuatan, terbagi atas tiga faktor yakni konsensus (concensus), konsisten (consistency) dan keunikan (distinctivens). Teori atribusi juga dapat dielaskan sebagai suatu proses untuk menginterpretasikan sebuah peristiwa, alasan dan sebab perilaku seseorang. Dalam teori ini menjelaskan perilaku seseorang terhadap peristiwa di sekitarnya dan alasan melakukan perilaku tersebut (Ikhsan dan Ishak, 2005). Sementara itu, Robbins dan Judge (2015) menjelaskan penyebab perilaku seseorang ditentukan oleh faktor internal dan faktor eksternal. Perilaku yang disebabkan oleh faktor internal adalah perilaku yang diyakini berada di bawah 
kendali atau berasal dari dalam diri individu seperti ciri kepribadian, motivasi atau kemampuan. Perilaku yang disebabkan oleh faktor eksternal adalah perilaku yang diyakini sebagai hasil dari sebab-sebab luar atau berasal dari luar diri individu seperti peralatan atau pengaruh sosial dari orang lain (Kusumastuti, 2012).

Maka peneliti menyimpulkan, bahwa perilaku manager dalam perusahaan merupakan cerminan dari lingkungan, kondisi sosial, dan karakteristik personal manajer. Karakteristik personal manager adalah penentu terhadap penilaian etis yang akan dibuat karena menjadi faktor internal yang mendorong manager untuk melakukan aktivitas. Jika manajer melakukan tindakan kejahatan atau tindakan yang merugikan bagi perusahaan maka perusahaan harus dapat cepat mendeteksi penyebab dari tindakan tersebut karena bisa jadi motivasi atau penyebab seseorang melakukan hal merugikan perusahaan itu berasal dari lingkungan, dan nilai sosial dari perusahaan sendiri atau dikarenakan faktor yang ada dari pribadi seseorang. Teori atribusi ini diharapkan dapat membantu manager dalam menangani masalah terkait penilaian etis manajer atas investasi berlebih pada CSR.

\section{Teori Tindakan Berpikir (Theory Reasoned Action)}

Theory of reasoned action (TRA) pertama kali diperkenalkan oleh Martin Fishbein dan Icek Ajzen pada tahun 1980.Teori ini menjelaskan hubungan antara keyakinan (belief), sikap (attitude), kehendak (intention), dan perilaku (behavior). Dalam teori ini dijelaskan bagaimana seseorang bertindak atas keyakinannya, sikap dan perilaku yang mendasari tindakan tersebut, serta membahas bagaimana keinginan seseorang berpengaruh terhadap perilaku orang tersebut. Selanjutnya, teori ini juga membahas tindakan yang akan dilakukan seseorang dari keinginannya. Sebab tidak semua orang memiliki pertimbangan yang sama dari keputusan yang dibuat.

\section{Penilaian Etis Manager atas Investasi Berlebih pada CSR}

Penilaian etis diartikan sebagai penentu apakah suatu tindakan benar atau salah (O'Fallon dan Butterfield, 2005).Chiu (2002) menyatakan bahwa penilaian atau pertimbangan etis adalah suatu pemikiran seorang individu secara utuh tentang suatu permasalahan yang sulit. Konsep penilaian etis diartikan sebagai suatu evaluasi dari suatu keputusan terhadap tindakan yang baik atau buruk yang dijadikan dasar dalam pembuatan keputusan etis. Investasi berlebihan pada CSR dapat dilihat sebagai isu etis karena beberapa hal. Pertama, CSR merupakan suatu proses yang didalamnya melibatkan nilai-nilai moral individu terutama manajer (Maclagan, 2012).

Kedua, keputusan manajer terkait dengan investasi pada CSR diliputi oleh konflik kewajiban antara kewajiban manajer untuk meningkatkan kinerja keuangan dan kewajiban manajer untuk meningkatkan kinerja sosial perusahaan dan konflik kewajiban inilah yang menjadi dilema etis bagi manajer (Maclagan, 2012). Ketiga, pada level individual, keputusan investasi pada CSR diliputi oleh konflik personal dikarenakan self-interest yang ada pada diri manajer. Manajer pada umumnya memiliki kepentingan pribadi dan tidak ingin kehilangan pekerjaannya, sehingga hal ini sering mempengaruhi keputusan-keputusannya. Sikap mengutamakan kepentingan pribadi ini merupakan salah satu elemen dilematis yang akan menyebabkan dilema etis bagi manajer (Maclagan, 2012). Ketiga hal tersebut memberikan keyakinan bagi peneliti untuk membingkai fenomena investasi berlebihan pada CSR sebagai isu etis.

\section{Skema Kompensasi dan Penilaian Etis}

Skema kompensasi menurut Wibowo (2011) adalah suatu imbalan yang ditawarkan organisasi kepada pekerja atas penggunaan tenaga kerjanya. Skema kompensasi disebut juga dengan imbalan dan pinalti. Dalam penelitian Kusuma dan Sholihin (2016) berhasil 
membuktikan bahwa manajer dengan skema kompensasi yang memberikan peluang untuk manajer bertindak tidak etis akan mempengaruhi pandangan manajer atas penilaian etis sehingga akan menilai tindakan tersebut sebagai tindakan yang etis. Sebaliknya, manajer dengan skema kompensasi yang tidak mendorong manajer untuk melakukan tindakan tidak etis akan tetap menilai tindakan tersebut sebagai tindakan tidak etis.

Dalam literatur keuangan, skema kompensasi mengaitkan langsung kinerja perusahaan dengan manfaat ekonomi yang akan didapat oleh manajer, dibuktikan dapat memberikan efek entrenchment atau efek alignment (Baxamusa, 2012). Efek entrenchment mendorong manajer untuk melakukan tindakan yang tidak etis, yang tidak sejalan dengan kepentingan pemegang saham, sedangkan efek alignment menyebabkan manajermelakukan tindakan yang sejalan dengan harapan pemegang saham. Terkait dengan investasi pada tanggung jawab sosial, skema kompensasi yang mengaitkan langsung manfaat ekonomi yang akan didapat oleh manajer dan kinerja perusahaan cenderung memberikan efek entrenchment. Skema kompensasi berbasis kinerja ini cenderung memotivasi manajer untuk melakukan investasi yang berlebihan yang dapat mendatangkan manfaat pribadi bagi manajer dalam jangka panjang berupa peningkatan dalam besaran kompensasi, sehingga dalam penelitian ini, skema kompensasi ini disebut dengan overinvestment inducing payscheme. Manajer berharap investasinya pada CSR akan direaksi positif oleh pemangku kepentingan sehingga akan meningkatkan reputasi perusahaan, yang selanjutnya akan meningkatkan laba perusahaan dalam jangka panjang. Peningkatan laba ini akan berdampak positif pada besaran kompensasi yang akan diterima manajer.

Penelitian yang dilakukan Wahyuni et al., (2019) meneliti pengaruh skema kompensasi dan gender terhadap penilaian etis manajer atas investasi berlebih pada CSR. Hasil penelitian tersebut menunjukkan bahwa skema kompensasi berpengaruh signifikan terhadap penilaian etis manajer atas investasi berlebih pada CSR.Manajer dengan overinvestment hindering payscheme (skema kompensasi tidak berbasis kinerja) lebih cenderung menilai investasi berlebihan pada CSR sebagai tindakan yang tidak etis dibandingkan manajer dengan overinvestment inducing payscheme (skema kompensasi berbasis kinerja). Hal ini mendukung teori atribusi bahwa penilaian etis dipengaruhi oleh faktor organisasional yaitu skema kompensasi.

Lei et al., (2014) membuktikan bahwa manager yang melakukan investasi berlebihan berharap akan mendapatkan kenaikan kompensasi di masa depan. Sebaliknya, skema kompensasi yang tidak dikaitkan langsung dengan manfaat ekonomi yang akan mengalir kepada manajer akan memicu manajer untuk tidak melakukan investasi yang berlebihan pada tanggung jawab sosial (dalam penelitian ini disebut overinvestment hindering payscheme) karena melakukan investasi yang berlebihan tidak akan memberikan manfaat pribadi tapi justru akan mendatangkan biaya pribadi bagi dirinya, ini menduga bahwa manager yang mendapatkan overinvestment-hindering pay scheme memiliki peluang yang lebih kecil untuk melakukan investasi berlebihan pada CSR dibandingkan dengan manager dengan overinvestment-inducing payscheme, sehingga lebih cenderung menilai investasi berlebihan pada CSR sebagai tindakan yang tidak etis.

Berdasarkan teori atribusi dan penelitian sebelumnya, maka penelitian ini menduga bahwa manager yang mendapatkan overinvestment hindering pay scheme memiliki peluang yang lebih kecil untuk melakukan investasi berlebihan pada CSR dibandingkan dengan manager dengan overinvestment inducing payscheme, sehingga lebih cenderung menilai investasi berlebihan pada CSR sebagai tindakan yang tidak etis. Oleh karena itu, hipotesis pertama penelitian ini dirumuskan sebagai berikut.

H1: Manajer dengan overinvestment hindering payscheme lebih cenderung menilai investasi berlebihan pada CSR sebagai tindakan yang tidak etis dibandingkan dengan manajer dengan overinvestment inducing payscheme. 


\section{Religiulitas dan Penilaian Etis}

Istilah religi berbeda dengan religiusitas. Religi lebih mengarah pada aspek formal yang berkaitan dengan aturan-aturan dan kewajiban-kewajiban. Sedangkan religiusitas merujuk pada aspek internalisasi dari aspek religi yang telah dihayati, diamalkan dan diimplementasikan dalam kehidupan sehari-hari (Mangunwijaya dalam Hisna, 2018). Menurut Nashori dan Mucharam (2002) dalam Hidayat (2018) religiusitas adalah seberapa jauh pengetahuan, seberapa kokoh keyakinan, seberapa pelaksanaan ibadah dan kaidah, dan seberapa dalam penghayatan atas agama yang dianut. Religiusitas didefinisikan sebagai suatu sistem terintegrasi dari keyakinan (belief), gaya hidup, aktivitas ritual dan institusi yang memberikan makna dalam kehidupan manusia dan mengarahkan manusia pada nilai-nilai suci atau nilai-nilai tertinggi (Glok dan Stark, 1969).

Religiusitas salah satu faktor yang mempengaruhi penilaian etis, terlihat dari penelitian Wong (2008) menyatakan ada hubungan yang kuat antara tingkat religious seseorang dengan penilaian etis yang dimiliki. Keyakinan agama yang kuat diharapkan mencegah perilaku ilegal melalui perasaan bersalah terutama dalam hal perilaku etis (Grasmick et al., 1991 dalam Basri, 2015). Sehingga, semakin religius individu maka individu tersebut semakin dapat mengendalikan perilakunya dan individu tersebut dapat menghindari untuk berbuat tidak etis. Religiusitas dapat terlihat dari berbagai sisi kehidupan manusia dan berdampak pada tingkah laku seseorang (Safrilsyah et al., 2010). Religiusitas dapat dibagi menjadi tiga dimensi, yaitu; akidah, ibadah (syariah), dan akhlak (ihsan) (Anshari dalam Safrilsyah et al., 2010).

Samroh (2019) menyatakan bahwa seorang yang memiliki religiulitas yang tinggi, maka akan tinggi pula perilaku yang dalam kehidupannya karena mampu menahan perilaku yang tidak baik dalam hal ini mendukung teori tindakan berpikir (theory reasoned action). Hasil penelitian Pratama et al., (2020), menyatakan dalam teori tindakan berpikir (theory reasoned action) membahas bagaimana seseorang bertindak atas keyakinan yang dimilikinya serta sikap dan perilaku yang mendasari tindakan tersebut.Sikap merupakan evaluasi kepercayaan atas perasaan positif atau negatif dari seseorang. Dalam hal ini religiusitas merupakan hal pribadi yang dimiliki oleh seseorang sehingga akan mempengaruhinya untuk bersikap. Karena agama adalah keyakinan yang dianut oleh seseorang. Sehingga niat seseorang untuk berperilaku positif dipengaruhi oleh faktor pribadi seseorang yang memutuskan untuk melakukan suatu tindakan atau berperilaku untuk melakukan investasi berlebih pada CSR.

Hasil penelitian Pratama et al., (2020) didukung oleh penelitian yang di lakukan Resty (2018) menyatakan tingkat religius seseorang tergantung kepada pribadi masingmasing. Semakin tinggi tingkat religious seseorang maka semakin besar potensi melakukan penilaian etis dalam mengambil keputusan. Orang yang tinggi tingkat keimanannya maka semakin etis mengambil keputusan yang dihadapi.Sedangkan seseorang yang rendah tingkat keimanannya maka semakin tidak etis dalam mengambil keputusan yang dihadapi.Penelitian yang dilakukan oleh Walker (2011) juga membuktikan bahwa semakin tinggi tingkat religius seseorang maka semakin etis orang tersebut dalam mengambil keputusan. Beberapa penelitian menunjukkan bahwa seseorang yang religius akan lebih etis dalam melakukan penilaian atas keputusan yang dihadapi daripada yang kurang religius. Religiusitas sangat berhubungan dengan penilaian etis manajer, sejalan dengan parameter dan filsafat dalam etika Islam, yang menuntut seseorang untuk memiliki integritas atas nilai-nilai etika dan moral (Pramono, 2012).

Terkait dengan penilaian etis manager atas investasi berlebih pada CSR, perbedaan penilaian etis manager yang lebih religius dengan manajer kurang religius dapat mempengaruhi penilaian etis manager dalam melakukan aktivitas CSR. Peneliti menduga bahwa manager yang lebih religius menilai bahwa investasi yang berlebihan pada CSR 
adalah tindakan yang tidak etis karena tindakan tersebut bersifat oportunistik dan dapat merugikan pemegang saham. Berdasarkan penelitian terdahulu diduga kemungkinan religiulitas mempengaruhi penilaian etis manager atas investasi berlebih pada CSR. Hipotesis yang diajukan dalam penelitian ini adalah:

H2: Manajer yang lebih religius cenderung menilai investasi berlebihan pada CSR sebagai tindakan yang tidak etis dibandingkan manajer yang kurang religius.

Berdasarkan urain latar belakang dan kajian teori yang telah dikemukakan sebelumnya dapat disimpulkan bahwa investasi berlebihan pada CSR dianggap sebagai tindakan tidak etis dimana suatu kedaan sulit yang dipengaruhi oleh komponen nilai-nilai etis dalam mengambil keputusan sehingga investasi berlebihan pada CSR menjadi isu-isu etis. Penilaian etis atas investasi berlebihan pada CSR dipengaruhi oleh dua faktor, yaitu faktor organisasioal dan individual. faktor organisasional adalah skema kompensasi yang terdiri dari skema kompensasi berbasis kinerja (overinvestment inducing payscheme) dan skema kompensasi tidak berbasis kinerja (overinvestment hindering payscheme) sedangkan Faktor individual dalam penelitian ini adalah relgiusitas. Maka kerangka konseptual yang dapat digambarkan terhadap pengaruh skema kompensasi dan religiusitas terhadap penilaian etis manajer atas investasi berlebihan pada CSR adalah sebagai berikut :

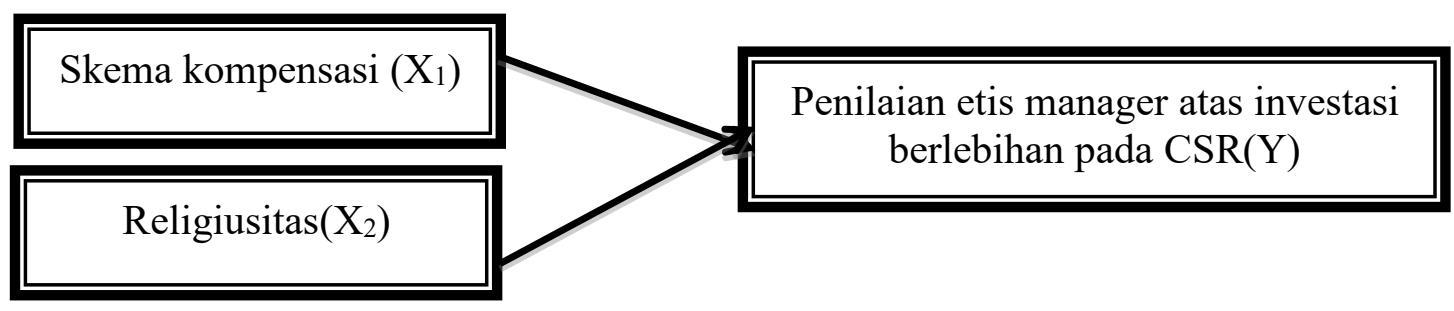

\section{Gambar 1. Kerangka Konseptual}

\section{METODOLOGI PENELITIAN}

Desain penelitian ini menggunakan desain kuasi eksperimen dengan faktorial $2 \times 2$. Tabel 1 berikut menyajikan desain eksperimen yang digunakan untuk penelitian ini.

Tabel 1. Desain Faktorial 2x2

\begin{tabular}{lccc}
\hline Penilaian etis manajer atas investasi & \multicolumn{2}{c}{ Skema Kompensasi } \\
berlebihan pada CSR (PEMAIBPCSR) & $\begin{array}{c}\text { Overinvestment } \\
\text { Inducing Paysheme }\end{array}$ & $\begin{array}{c}\text { Overinvestment } \\
\text { Hindering Payscheme }\end{array}$ \\
\hline Religiulitas & Kurang Religius & OIPKR & OHPKR \\
& Lebih Religius & OIPLR & OHPLR \\
\hline
\end{tabular}

Teknik pengambilan sampel yang digunakan dalam penelitian ini adalah Purposive Sampling. Teknik ini merupakan teknik pengambilan sampel berdasarkan beberapa kriteria yang telah ditetapkan serta harus memenuhi dari kriteria tersebut. Beberapa kriteria yang harus dipenuhi antara lain adalah mahasiswa Magister Managemen yang masih aktif menjalankan kegiatan perkuliahan dan terdaftar pada program studi Magister Managemen di Universitas Negeri Padang angkatan 2019 dianggap memahami perilaku etis dan perilaku tidak etis manager.

Jenis data pada penelitian ini adalah data subjek berupa instruksi, skenario kasus, dan kuesioner demografi. Data yang digunakan dalam penelitian ini adalah data kuantitatif dengan menggunakan skala likert. Teknik pengumpulan data pada penelitian ini dengan menyebar 57 kuesioner. Kuesioner yang dikembalikan dan dapat diolah adalah 53 kuesioner. Instrumen penelitian pada penelitian ini dikembangkan berdasarkan penelitian sebelumnya yaitu penelitian 
yang dilakukan oleh Kusuma dan Sholihin (2016). Pertanyaan pada instrumen skema kompensasi penelitian terbagi atas tiga bagian, pada bagian pertama berisi pertanyaan seputar data demografi responden, bagian kedua berisikan skenario. Skenario terdiri dari dua jenis, skenario pertama adalah skenario Overinvestment Inducing Payscheme dengan kondisi skema kompensasi berbasis kinerja. Skenario kedua adalah skenario Overinvestment Hindering Payscheme dengan kondisi skema kompensasi tidak berbasis kinerja. Masingmasing partisipan akan mendapatkan satu skenario. Partisipan diminta untuk merespon satu butir pertanyaan tentang penilaian etis manager atas investasi berlebih pada CSR.Pada bagian ketiga, Pengukuran penilaian etis manager atas investasi berlebih pada CSR dengan skala likert 1-5 antara jawaban sangat tidak etis hingga etis.Instrument religiulitas diukur dengan memberikan kuesioner yang terbagi atas 3 aspek religi yang digunakan oleh Krauss dan Hamzah (2011), yaitu; akidah, ibadah, dan ahklak. Pengukuran yang digunakan untuk mengukur variabel religiusitas adalah skala likert dengan satuan poin 1-5 antara jawaban sangat tidak setuju hingga sangat setuju.

Uji coba instrumen (pilot test) dilakukan sebelum kuesioner dibagikan kepada peserta penelitian. Kuesioner diuji terlebih dahulu untuk mengevaluasi apakah peryataan relevan dan mudah dimengerti atau tidak oleh peserta dengan menghitung validitas dan reliabilitas kuesioner uji coba. Uji coba instrumen ini diberikan pada mahasiswa Magister Management di Universitas Negeri Padang yang tidak termasuk dalam peserta penelitian. Sebanyak 30 orang berpartisipasi pada uji coba ini. Pada penelitian ini khususnya kuesioner penelitian akan diuji kevalidan beserta kereliabilitasnya terhadap masing-masing item pertanyaan yang ada. Dalam pengujian validitas terhadap kuesioner dilakukan dengan menggunakan validitas item. Uji validitas ini menggunakan korelasi Bivariate Pearson (Produk Momen Pearson). Jika nilai Sig. (2-tailed) $<0,05$ dan Pearson Correlation bernilai positif, maka instrumen atau item-item pertanyaan berkorelasi signifikan terhadap skor total (dinyatakan valid). Analisis ini dilakukan dengan cara mengkorelasikan masing-masing skor item dengan skor total. Kuesioner untuk skema kompensasi dan penilaian etis manajer atas investasi berlebih pada CSR tidak dapat dicari kevalidan datanya karena merupakan uji manipulasi yang dilakukan oleh peneliti dan hanya mengandung 2 unsur item pernyataan. Dari hasil olah data menggunakan SPSS, didapatkan hasil bahwa nilai Sig. (2-tailed) yang dihasilkan setiap item pertanyaan $<0,05$ yang artinya bahwa tiap item dinyatakan valid. Sama seperti uji validitas diatas, uji reliabilitas hanya dilakukan pada kuesioner religiulitas dengan hasil Cronbach's Alpha sebesar 0,970 yang lebih besar dari 0,60 sehingga dapat dinyatakan reliabel.

\section{HASIL DAN PEMBAHASAN \\ Gambaran Umum Objek Penelitian}

Partisipan dalam penelitian ini adalah mahasiswa program studi Magister Managemen di Universitas Negeri Padang angkatan 2019. Total kuesioner yang disebar sebanyak 57 kuesioner. Dari total 57 kuesioner yang disebar, setelah dilakukan manipulation check ada 4 kuesioner yang tidak lulus uji manipulasi sehingga jumlah kuesioner yang dapat diolah adalah 53 kuesioner. Jumlah kuesioner yang digunakan pada penelitian ini hanya kuesioner yang telah diisi dengan lengkap dan sesuai dengan ketentuan. Sebagian besar partisipan yang ikut serta dalam eksperimen ini berjenis kelamin perempuan sebanyak 32 orang atau $60,4 \%$, sedangkan responden laki-laki berjumlah 21 orang atau $39,6 \%$.

\section{Statistik Deskriptif}

Analisis statistik deskriptif antar variabel penelitian bisa dilihat pada Tabel 2 berikut ini: 
Tabel 2

Statistik Deskriptif Penilaian Etis Manager Atas Investasi Berlebih pada CSR

\begin{tabular}{lccc}
\hline \multicolumn{1}{c}{ Skema Kompensasi } & \multicolumn{2}{c}{ Religiulitas } & \multirow{2}{*}{ Total } \\
\cline { 2 - 3 } & Kurang Religius & Lebih Religius & \\
\cline { 2 - 3 } Skema Kompensasi Berbasis Kinerja & $N=13$ & $N=13$ & $N=26$ \\
(OIP) & $M=2,31$ & $M=3,31$ & $M=2,81$ \\
& $S D=0,751$ & $S D=0,630$ & $S D=0,849$ \\
\hline \multirow{2}{*}{ Skema Kompensasi tidak berbasis } & $N=11$ & $N=16$ & $N=27$ \\
Kinerja (OHP) & $M=2,73$ & $M=4,00$ & $M=3,48$ \\
& $S D=0,647$ & $S D=0,516$ & $S D=0,849$ \\
\hline \multirow{2}{*}{ Total } & $N=24$ & $N=29$ & $N=53$ \\
& $M=2,50$ & $M=3,69$ & $M=3,15$ \\
\hline
\end{tabular}

Sumber : data penelitian yang diolah, 2021

Hasil penelitian menunjukkan skema kompensasi berbasis kinerja (OIP) yang berjumlah 26 partisipan mempunyai nilai rata-rata 2,81 dengan standar deviasi 0,849 dengan variabel skema kompensasi tidak berbasis kinerja (OHP) yang berjumlah 27 partisipan mempunyai nilai rata-rata 3,48 dengan standar deviasi 0,849 . Dari nilai rata-rata yang dihasilkan dapat disimpulkan bahwa partisipan yang diberi skenario skema kompensasi tidak berbasis kinerja (OHP) lebih cenderung menilai investasi berlebih pada CSR sebagai tindakan yang tidak etis di bandingkan partisipan yang di beri skenario skema kompensasi berbasis kinerja (OIP).

Pada perbandingan penilaian etis pada variabel skema kompensasi dan religious didapatkan hasil nilai rata-rata untuk skema kompensasi berbasis kinerja (OIP) dari partisipan dengan tingkat kurang religius sebesar 2,31 dengan standar deviasi 0,751 sedangkan untuk skema kompensasi berbasis kinerja (OIP) dari partisipan dengan tingkat lebih religius mempunyai nilai rata-rata 3,31 dengan standar deviasi 0,630 . Dari nilai ratarata tersebut dapat disimpulkan bahwa partisipan yang mendapat skenario skema kompensasi berbasis kinerja (OIP) dengan tingkat kurang religius maupun lebih religius menilai investasi berlebih pada CSR sebagai tindakan yang etis.

Pada perbandingan penilaian etis pada variabel skema kompensasi dan religious untuk skema kompensasi tidak berbasis kinerja (OHP) dari partisipan dengan tingkat kurang religius mempunyai nilai rata-rata 2,73 dengan standar deviasi 0,647 . Sementara partisipan yang diberi skenario skema kompensasi tidak berbasis kinerja (OHP) dari partisipan dengan tingkat lebih religius mempunyai nilai rata-rata 4,00 dengan standar deviasi 0,516. Dari nilai rata-rata tersebut dapat disimpulkan bahwa partisipan yang mendapat skenario skema kompensasi yang tidak berbasis kinerja baik dengan tingkat kurang religius maupun lebih religius menilai investasi berlebih pada CSR sebagai tindakan yang tidak etis.

Tabel 3.

Tingkat Religiusitas berdasarkan Subskala Islamic Religiousity

\begin{tabular}{lcccc}
\hline & Low & Moderat & High & Total Responden \\
\hline Islamic Worldview (Aqidah) & $\mathbf{1 3}$ & $\mathbf{3 9}$ & $\mathbf{1}$ & 53 \\
a. Worldly & 6 & 46 & 1 & 53 \\
b. Spiritual & 17 & 34 & 2 & 53 \\
\hline Religious Personality & $\mathbf{0}$ & $\mathbf{2 5}$ & $\mathbf{2 8}$ & 53 \\
a. Ritual (ibadah) & 0 & 21 & 32 & 53 \\
b. Mu'amalah (ahklak) & 2 & 28 & 23 & 53 \\
\hline
\end{tabular}

Sumber : data penelitian yang diolah, 2021 
Hasil penelitian menunjukkan bahwa untuk skala akidah terdapat 28 partisipan $(52,8 \%)$ memiliki tingkat akidah yang tinggi dan 25 partisipan $(47,2 \%)$ memiliki tingkat akidah yang moderat. Untuk skala ibadah terdapat 32 partisipan $(60,4 \%)$ memiliki ibadah yang tinggi dan 21 partisipan $(39,6 \%) \%$ memiliki tingkat akidah yang moderat. Sedangkan untuk skala mu'amalah 23 partisipan $(43,4 \%)$ memiliki tingkat mu'amalah yang tinggi, 28 partisipan $(52,8 \%)$ memiliki tingkat mu'amalah yang moderat dan 2 partisipan memiliki tingkat mu'amalah yang rendah. Secara keseluruhan tingkat religiusitas sampel penelitian berada pada skala moderat dan tinggi. Hasil penelitian ini membuktikan bahwa partisipan memiliki tingkat religiusitas yang cukup tinggi.

\section{Uji Asumsi Klasik}

Uji asumsi klasik meliputi uji normalitas dan uji homogenitas. Pengujian Normalitas terhadap data menggunakan uji statistik Kolmogorov-Smirnov (KS) dengan hasil nilai signifikansi 0,091 , hal ini berarti data terdistribusi normal karena nilai signifikani $>0,05$. Hasil pengujian homogenitas diperoleh nilai sgnifikansi $>0,05$ yaitu 0,156 , artinya variabel yang diteliti homogen.

\section{Uji Hipotesis}

Teknik analisis data yang digunakan untuk menguji kebenaran hipotesis yang diajukan adalah dengan menggunakan analisis uji Two Way ANOVA (Analysis Of Variance) dan uji Non Parametrik yaitu uji Mann-Whitney. Berikut hasil uji Two Way ANOVA pada penelitianini.

Hipotesis pertama $\left(\mathrm{H}_{1}\right)$ memprediksi bahwa manajer dengan overinvestment hindering payscheme lebih cenderung menilai investasi berlebihan pada CSR sebagai tindakan yang tidak etis dibandingkan dengan manajer dengan overinvestment inducing payscheme. Pada Tabel 4 merupakan hasil uji parametrik yang menunjukkan mean square senilai4,024 dan nilai signifikansi uji analisis Two Way ANOVA sebesar $0,0003<0,05$. Hal ini membuktikan bahwa manajer dengan overinvestment hindering payscheme lebih cenderung menilai investasi berlebihan pada CSR sebagai tindakan yang tidak etis dibandingkan dengan manajer dengan overinvestment inducing payscheme adalah benar.

Hipotesis pertama memiliki tambahan uji nonparametrik. Uji nonparametrik ini bertujuan untuk kelengkapan hasil penelitian yang yang memiliki data yang tidak berdistribusi normal.Uji non parametrik yang digunakan adalah uji Mann-Whitney.Tabel 4 menunjukkan mean rank untuk overinvestment hindering payscheme (skema kompensasi tidak berbasis kinerja) sebesar 32,48 lebih tinggi dari pada overinvestment inducing payscheme (skema kompensasi berbasis kinerja) sebesar 21,31. Nilai signifikansi yang ditunjukkan oleh nilai asymp.sig.yang dihasilkan sebesar 0,005 lebih kecil dari 0,05. Dengan demikian dari hasil analisis tersebut dapat ditarik kesimpulan bahwa hipotesis pertama $\left(\mathrm{H}_{1}\right)$ terpenuhi. 
Tabel 4.

Hasil Uji Hipotesis Parametrik dan Non-Parametrik

\begin{tabular}{|c|c|c|c|c|c|c|}
\hline \multicolumn{4}{|c|}{ Uji Parametrik } & \multicolumn{3}{|c|}{ Uji Non Parametrik } \\
\hline \multicolumn{4}{|c|}{ Uji Two way Anova } & \multicolumn{3}{|c|}{ Uji Mann-Whitney } \\
\hline & $\begin{array}{l}\text { Mean } \\
\text { Square }\end{array}$ & $\mathrm{F}$ & Sig. & & $\begin{array}{l}\text { Mean } \\
\text { Rank }\end{array}$ & Sig. \\
\hline Correct Model & 7,691 & 19,110 & 0,000 & $\begin{array}{l}\text { Skema Kompensasi } \\
\text { Berbasis Kinerja } \\
\text { (OIP) }\end{array}$ & 21,31 & \\
\hline Intercept & 495,813 & 1231,973 & 0,000 & $\begin{array}{l}\text { Skema Kompensasi } \\
\text { Tidak Berbasis } \\
\text { Kinerja (OHP) }\end{array}$ & 32,48 & 0,005 \\
\hline Skema Kompensasi & 4,024 & 9,998 & 0,003 & Kurang Religius & 16,21 & \\
\hline Religiulitas & 16,811 & 41,771 & 0,000 & Lebih Religius & 35,93 & 0,000 \\
\hline $\begin{array}{l}\text { Skema } \\
\text { kompensasi*religiulitas }\end{array}$ & ,242 & ,602 & 0,442 & & & \\
\hline
\end{tabular}

Sumber : data penelitian yang diolah, 2021

Hipotesis pertama $\left(\mathrm{H}_{2}\right)$ memprediksi bahwa manajer yang lebih religius cenderung menilai investasi berlebihan pada CSR sebagai tindakan yang tidak etis dibandingkan manajer yang kurang religius. PadaTabel 4 merupakan hasil uji parametrik yang menunjukkan mean square senilai 16,811 dan nilai signifikansi uji analisis Two Way ANOVA sebesar $0,000<0,05$. Dengan demikian, dapat diambil kesimpulan bahwa manajer yang lebih religius cenderung menilai investasi berlebihan pada CSR sebagai tindakan yang tidak etis dibandingkan manajer yang kurang religius.

Hipotesis kedua memiliki tambahan uji nonparametrik dengan menggunakan uji Mann-Whitney. Tabel 4 menunjukkan mean rank untuk manager lebih religius sebesar 35,93 lebih tinggi dari pada manager kurang religius sebesar 16,21. Nilai signifikansi yang ditunjukkan oleh nilai asymp.sig.yang dihasilkan adalah 0,000 lebih kecil dari 0,05. Dengan demikian hipotesis kedua (H2) terpenuhi.

\section{PEMBAHASAN}

\section{Pengaruh skema kompensasi terhadap penilaian etis manager atas investasi berlebih pada CSR}

Hipotesis pertama (H1) yang dirumuskan dalam penelitian ini adalah manajer dengan overinvestment hindering payscheme lebih cenderung menilai investasi berlebihan pada CSR sebagai tindakan yang tidak etis dibandingkan dengan manajer dengan overinvestment inducing payscheme. Berdasarkan hasil uji hipotesis dengan uji ANOVA dua arah (two way ANOVA), menunjukkan bahwa variabel skema kompensasi mendapatkan nilai signifikan 0,003 . Karena nilai signifiknasi $<\alpha=0,05$ maka dapat diambil kesimpulan bahwa skema kompensasi berpengaruh signifikan terhadap penilaian etis manager atas investasi berlebih pada CSR. Hal ini menunjukkan bahwa manajer dengan overinvestment hindering payscheme lebih cenderung menilai investasi berlebihan pada CSR sebagai tindakan yang tidak etis dibandingkan dengan manajer dengan overinvestment inducing payscheme. Dengan demikian Hipotesis 1 terpenuhi.

Berdasarkan hasil hipotesis 1 diterima yang sejalan dengan penelitian Kusuma dan Sholihin (2016) yang menyatakan bahwa Manager dengan overinvestment-hindering pay scheme lebih cenderung menilai investasi berlebihan pada tanggung jawab sosial sebagai tindakan yang tidak etis dibandingkan dengan manager dengan overinvestment-inducing pay scheme. Penelitian ini diperkuat dengan hasil penelitian Wahyuni et al., (2019) meneliti pengaruh skema kompensasi dan gender terhadap penilaian etis manajer atas investasi berlebih pada CSR. Hasil penelitian tersebut menunjukkan bahwa skema kompensasi berpengaruh signifikan terhadap penilaian etis manajer atas investasi berlebih pada CSR. 
Manajer dengan overinvestment hindering payscheme (skema kompensasi tidak berbasis kinerja) lebih cenderung menilai investasi berlebihan pada CSR sebagai tindakan yang tidak etis dibandingkan manajer dengan overinvestment inducing payscheme (skema kompensasi berbasis kinerja).

Hasil penelitian lainnya yang sejalan dengan hasil penelitian ini adalah oleh Baxamusa (2012) menunjukkan bahwa manajer yang kompensasinya diukur dari peningkatan laba perusahaan dapat memberikan efek entrenchment dan alignment. Efek entrenchment adalah suatu efek yang mendorong manajer untuk melakukan tindakan tidak etis yang tidak sejalan dengan kepentingan pemegang saham, sedangkan efek alignment adalah efek yang menyebabkan manajer melakukan tindakan yang sejalan dengan harapan pemegang saham.

Hasil penelitian ini konsisten dengan teori atribusi yang dikembangkan oleh Fritz Heider, dimana individu akan menilai suatu tindakan etis atau tidak etis melalui alasan atau sebab perilakunya, khususnya dalam penelitian ini adalah skema kompensasi. Perilaku yang dilakukan oleh manajerpada penelitian ini cerminan dari karakteristik personal manajer. Pada dasarnya karakteristik personal seorang manajer merupakan salah satu penentu terhadap penilaian etis yang akan dibuat karena merupakan suatu faktor internal yang mendorong seseorang untuk melakukan suatu aktivitas. Manajer yang mendapatkan overinvestment hindering payscheme yang kompensasinya tidak diukur dari laba yang dihasilkan perusahaan, akan menyebabkan individu tersebut menilai investasi berlebih pada CSR adalah tindakan yang tidak etis dibandingkan manajer dengan overinvestment inducuing payscheme yang kompensasinya diukur dari kinerja perusahaan atau laba yang dihasilkan perusahaan.

\section{Pengaruh religiulitas terhadap penilaian etis manager atas investasi berlebih pada CSR}

Hipotesis pertama $(\mathrm{H} 2)$ yang dirumuskan dalam penelitian ini adalahmanajer yang lebih religius cenderung menilai investasi berlebihan pada CSR sebagai tindakan yang tidak etis dibandingkan manajer yang kurang religious. Berdasarkan hasil uji hipotesis dengan uji ANOVA dua arah (two way ANOVA), menunjukkan bahwa variabel religiulitas mendapatkan nilai signifikan 0,000 . Karena nilai signifiknasi $<\alpha=0,05$ maka dapat diambil kesimpulan bahwa religiulitas berpengaruh signifikan terhadap penilaian etis manager atas investasi berlebih pada CSR. Hal ini menunjukkan bahwa manajer yang lebih religius cenderung menilai investasi berlebihan pada CSR sebagai tindakan yang tidak etis dibandingkan manajer yang kurang religius. Dengan demikian hipotesis 2 terpenuhi.

Hasil penelitian ini sejalan dengan hasil penelitian Samroh (2019) menyatakan bahwa seorang yang memiliki religiulitas yang tinggi, maka akan tinggi pula perilaku yang dalam kehidupannya karena mampu menahan perilaku yang tidak baik. Sejalan pula dengan hasil penelitian Pratama et al., (2020) didukung oleh penelitian yang di lakukan Resty (2018) menyatakan tingkat religius seseorang tergantung kepada pribadi masing-masing. Semakin tinggi tingkat religious seseorang maka semakin besar potensi melakukan penilaian etis dalam mengambil keputusan. Orang yang tinggi tingkat keimanannya maka semakin etis mengambil keputusan yang dihadapi.Sedangkan seseorang yang rendah tingkat keimanannya maka semakin tidak etis dalam mengambil keputusan yang dihadapi.

Dalam penelitian ini mendukung teori tindakan berpikir (theory reasoned action), dimana seseorang bertindak atas keyakinan yang dimilikinya serta sikap dan perilaku yang mendasari tindakan tersebut. Sikap merupakan evaluasi kepercayaan atas perasaan positif atau negatif dari seseorang. Dalam hal ini religiusitas merupakan hal pribadi yang dimiliki oleh seseorang sehingga akan mempengaruhinya untuk bersikap. Karena agama adalah keyakinan yang dianut oleh seseorang. Sehingga niat seseorang untuk berperilaku positif dipengaruhi oleh faktor pribadi seseorang yang memutuskan untuk melakukan suatu tindakan atau berperilaku untuk melakukan investasi berlebih pada CSR. Terkait dengan penilaian etis 
manager atas investasi berlebih pada CSR, perbedaan penilaian etis manager yang lebih religius dengan kurang religius dapat mempengaruhi penilaian etis manager dalam melakukan aktivitas CSR. Manager yang lebih religius menilai bahwa investasi yang berlebihan pada CSR adalah tindakan yang tidak etis karena tindakan tersebut bersifat oportunistik dan dapat merugikan pemegang saham.

\section{SIMPULAN, KETERBATASAN, DAN SARAN Kesimpulan}

Skema kompensasi berpengaruh signifikan terhadap penilaian etis manager atas investasi berlebih pada CSR. Hal ini menunjukkan manajer dengan overinvestment hindering payscheme lebih cenderung menilai investasi berlebihan pada CSR sebagai tindakan yang tidak etis dibandingkan dengan manajer dengan overinvestment inducing payscheme. Hasil penelitian ini mendukung teori atribusi yang menyatakan bahwa skema kompensasi merupakan faktor organisasional yang mempengaruhi penilaian etis individu (H1).

Religiulitas berpengaruh signifikan terhadap penilaian etis manager atas investasi berlebih pada CSR. Hal ini menunjukkan bahwa manajer yang lebih religius cenderung menilai investasi berlebihan pada CSR sebagai tindakan yang tidak etis dibandingkan manajer yang kurang religius. Hal ini mendukung teori tindakan berpikir (theory reasoned action) bahwa religiusitas adalah hal pribadi yang dimiliki oleh seseorang sehingga akan mempengaruhinya untuk bersikap. Karena agama adalah keyakinan yangdianut oleh seseorang,maka niat seseorang untuk berperilaku positif dipengaruhi oleh faktor pribadi seseorang yang memutuskan untuk melakukan suatu tindakan atau berperilaku untuk melakukan investasi berlebih pada CSR (H2).

\section{Keterbatasan dan Saran}

Pada penelitian ini masih ada responden yang kurang memahami prosedur penelitian yang dijelaskan melalui manipulasi yang diberikan menyebabkan masih ada responden yang tidak lolos uji manipulasi.Untuk itu, disarankan pada peneliti selanjutnya dapat memberikan penjelasan mengenai perlakuan yang diberikan kepada partisipan kuasi eksperimen secara lebih baik sehingga responden dapat memahami penelitian dengan baik dan lolos uji manipulasi.

Fokus penelitian ini hanya pada satu faktor organisasional yaitu skema kompensasi dan penelitian ini juga hanya menggunakan satu faktor individual yaitu religiulitas. Penelitian selanjutnya disarankan untuk memperluas penelitian dengan memasukkan varabel faktor organisasional lain yang belum diukur seperti kode etik, pelatihan, iklim organisasi dan budaya organisasi. Sementara faktor individual yang banyak diuji adalah usia, pendidikan, pekerjaan, pengalaman kerja, komitmen organisasi dan faktor kepribadian. Penelitian ini hanya dilakukan pada mahasiswa Magister Managemen Universitas Negeri Padang. Peneliti berikutnya disarankan untuk memilih tempat penelitian yang berbeda dan memperluas objek penelitian agar didapatkan hasil penelitian yang akurat.

\section{DAFTAR PUSTAKA}

Basri, Yesi, M. (2015).Pengaruh gender, religiusitas dan sikap love of money pada persepsi etika penggelapan pajak mahasiswa Akuntasi.Jurnal Ilmiah Akuntansi dan Bisnis, 10(1).

Baxamusa, M. (2012). The relationship between underinvestment, overinvestment and CEO's compensation, Review of Pacific Basin Financial Markets and Policies 15 (3): 1250014-1-1250014-26. 
Chiu, R. K. (2002). Ethical judgement, locus of control, and whistleblowing intention: a case study of mainland chinese MBA students. Managerial Auditing Journal, 17, 581-587.

Ferreira, P., dan Oliveira, De, E. R. (2014). Does corporate social responsiblity impact on employee engagement?.Joournal of Workplace Learning, 26(3/4), 232-247.

Glock, C. Y., dan Stark, R. 1965. Religion andsociety in tension.Chicago: Rand McNally.

Heider, Fritz. (1958). ThePpsychology of Interpersonal Relations. New York: Wiley.

Hemingway, C., dan P. Maclagan. (2004). Managers' personal values as drivers of corporate social responsibility, Journal of Business Ethics 50 (1): 33-44.

Hidayat, Farid. (2018). Pengaruh etika bisnis islam dan religiusitas terhadap perilaku bisnis syariah pada pengurus Hipsi Kota Semarang. Semarang: Fakultas Ekonomi dan Bisnis Islam Universitas Islam Negeri Walisongo Semarang.

Hisna, Qadra. (2018). Pengaruh Religiusitas Terhadap Keputusan Akuntan di Sumatera Barat.Skripsi.Jurusan Akuntansi Fakultas Ekonomi Universitas Negeri Padang.

Hobson, J. L., M. J. Mellon, dan D. E. Stevens. (2011). Determinants of moral judgments regarding budgetary slack: An experimental examination of pay scheme and personal values, Behavioral Research in Accounting, 23 (1): 87-107.

Hutahahean, M. U. and Hasnawati. 2015. Pengaruh Gender, Religiusitas, dan Prestasi Belajar terhadap Perilaku Etis Akuntan Masa Depan. e-Journal Akuntansi Trisakti, 2 (1), pp.49-66.

Ikhsan, Arfan dan Ishak, Muhammad.(2005). Akuntansi Keperilakuan. Jakarta: Salemba Empat.

Kao, E. H., H. Fung, dan Q. Li. 2014. What explains corporate social responsibility engagement in Chinese firms?,The Chinese Economy 47 (5-6): 50-80.

Kinasih, Hayu, W., Oktafiyani, Melati., dan Yovita, Lenni. (2018). Keterkaitan antara corporate social responsibility terhadap manajemen laba : sebuah perspektif teori agency. Jurnal Penelitian Ekonomi dan Bisnis, 3 (2): 101-109.

Kusuma, Poppy Dian Indira., dan Sholihin Mahfud.(2016). Penilaian Etis Manager Atas Investasi Berlebihan Pada CSR.Lampung.Simposium Nasional Akuntansi, 19 : 2016.

Kusumastuti, Nur Ratri. (2012). Analisis Faktor-Faktor yang berpengaruh terhadap kecenderungan kecurangan akuntansi dengan perilaku tidak etis sebagai variabel intervening. Semarang: Unversitas Diponegoro.

Lei, Z., C. Mingchao, Y. Wang, dan J. Yu. 2014. Managerial private benefits and overinvestment, Emerging Markets Finance \& Trade 50 (3): 126-161.

Lubis, Arfan Ikhsan. (2014). Akuntansi Keperilakuan. Jakarta: Salemba Empat.

Luthans, F. (2005).Organizational Behavior.Seventh Edition. New York: McGraw-Hill, Inc.

Maclagan, P. (2012). Conflicting obligations, moral dilemmas and development of judgment through business ethics education, Business Ethics: A European Review 21 (2): 183197.

McWilliams, A. dan Siegel, D. (2000).Corporate socialresponsibility dan financialperformance: correlation ormisspecification. Strategic Management Journal, 21(5), 603-9.

O'Fallon, M. J., dan Butterfield, K. D. (2005). A review of the empirical ethical decisionmaking literature: 1996-2003. Journal of Business Ethics, 59, 375-413.

Petrovits, C. 2006. Corporate-sponsored foundations and earnings management, Journal of Accounting and Economics 41 (3): 335-361.

Pramono, H. (2012). Pelaku Etis dalam Perspektif Etika Islam.

Pratama, Azhari; Helmy, Herlina \& Afriyenti, Mayar. (2020). Pengaruh Usia dan Religiusitas Terhadap Keyakinan Etis Pada Akuntan. Jurnal Eksplorasi Akuntansi, 2(1), Seri D, 2407-2427. 
Prior, D., J. Surroca, dan J. A. Tribo. 2008. Are socially responsible managers really ethical? Exploring the relationship between earnings management and corporate social responsibility, Corporate Governance 16 (3): 160-177.

Rahmi, Febri dan Sovia, Asni.(2017). Dampak sistem pengendalian internal, prilaku tidak etis, dan moralitas manajemen terhadap kecenderungan kecurangan akuntansi pada perusahaan developer di Pekanbaru.Jurnal Al-Iqtishad, 1(13).

Resty, Nadia, N.H. (2018). Pengaruh Religiusitas dan Gender Terhadap Penilaian Etis (Ethical Judgement) Mahasiswa Akuntansi Minangkabau.Jurnal EcoGen, 1(4).

Robbins, Stephen P dan Timothy A. Judge.(2015). Perilaku Organisasi.Edisi ke16.Terjemahan oleh Ratna Saraswati dan Febriella Sirait. Jakarta: Salemba Empat.

Safrilsyah,Baharudin R., Duraseh, N. (2010). Religiusitas Dalam Perspektif Islam:Suatu Kajian Psikologi Agama. Substantia, 12 (2): 399-412.

Samroh. (2019) Analisis Pengaruh Religiusitas dan Gender Terhadap Persepsi Etis Akuntan Publik Dengan Love Of Money Sebagai Variabel Intervening (Studi Kasuspada Kantor Akuntan PublikKota Semarang). Skripsi.Fakultas Ekonomi dan Bisnis, Universitas Islam Negeri Walisongo Semarang.

Thoyibatun, Siti. (2012). Faktor-Faktor Yang Berpengaruh Terhadap PerilakuTidak Etis Dan Kecenderunagn Kecurangan Akuntansi Serta AkibatnyaTerhadap Kinerja Organisasi.Ekuitas Jurnal Ekonomi dan Keuangan, 16(2), 245-260.

Wahyuni, Z.M.S., dan Dwita, S., Halmawati. (2019). Pengaruh skema kompensasi dan gender terhadap penilaian etis manager atas investasi berlebih pada CSR.Jurnal Eksplorasi Akuntansi, 1(3), Seri C, 1233-1243.

Wibowo.(2011). Manajemen Kinerja.Edisi 3. Jakarta: Rajawali Pers.

Wood, D.J. (2010). Measuring corporate social performance: Areview, International Journal of Management Reviews: 50-84.

Woodbine, G. P. (2009). Does Religiosity Influence Ethical Sensitivity? An Investigation on Malaysia Future Accountants.Malaysian Accounting Review, 8, 17- 41. 